\title{
Unusual Details of Everyday Life from the Notary Registry of Petrus, Called Perençanus, a Notary from Zadar (1365-1392)
}

Most of the contracts from the unpublished notary registry of the notary Petrus from Zadar, known as Perençanus (1365-1392) provide only the most basic information about the contractors, the type of legal business and its subject matter, witnesses, officials, etc. because of their usual formulaic nature. In this paper, we shall deal with contracts that break this uniformity common to medieval notary records by presenting unusual and interesting details of people's lives, largely found in the formulae contrahentes, res and causa. The content of these contracts is analyzed at two levels: within the context of studying the medieval mentality and within the linguistic context.

Keywords: the Middle Ages, Zadar, notary records, Petrus Perençanus, medieval Latin, written discourse, spoken discourse

\section{Introduction}

When medieval notary records are mentioned, the first thing that comes to mind is their formulaic nature. When a notary drew up a contract, he incorporated the basic information on the contractors and the subject matter of their legal business into a set of legal formulae or clauses that he had learned during his studies owing to the notarial forms of the time, such as those found in the well-known handbook by Professor Rolandinus Pasagerii. ${ }^{1}$ Contracts which were drawn up

* Anita Bartulović, Department of Classical Philology, University of Zadar, Obala kralja Petra Krešimira IV. br. 2, 23000 Zadar, Croatia, E-mail: abartulo@unizd.hr

** This paper was presented in its shortened form under the title "Izvan okvira pravnih formula" [Beyond Legal Formulae] at the international conference Natales grate numeras?, Zadar, Croatia, 7-8 April 2017. I'm grateful to the reviewers for all their suggestions and remarks that have contributed to the improvement of this paper.

1 On medieval notarial handbooks see: Branka Grbavac, "Notarijat na istočnojadranskoj obali od druge polovine 12. do kraja 14. stoljeća" [Notariate on the Eastern Adriatic Coast from the Second Half of the Twelfth to the End of the Fourteenth Century] (doktorska disertacija, Sveučilište u Zagrebu, 2010), 78. 
in this way and found in notary registers offer a lot of information in the contrahentes and res formulae, ${ }^{2}$ and this is especially true for the Zadar Commune in the second half of the 14th century. This information can be reduced to statistical values in terms of the amounts recorded in debentures, the prices of immoveable and movable property, the size of land lots, the value of dowries, the amount of money invested in various business ventures, etc., embedded in a broader picture of the economic development of the Zadar Commune in a certain period. As such, they lend themselves to prosopographic analyses of particular social and professional groups as important stakeholders in the social and economic development. ${ }^{3}$ However, the phrase "a lot of information" should be understood as a figure of speech, considering the degree to which the archival material has been preserved. When the notary records from Zadar in the second half of the fourteenth century are compared to those of earlier periods, it is obvious that, diachronically speaking, the cumulative number of records was getting larger, ${ }^{4}$ but in terms of the synchronic cross section, there are various problems when one tries to conduct research, as many unknowns emerge because of the fragmentation of the records due to physical damage or loss.

2 On the diplomatic structure of individual notary records see: Grbavac, "Notarijat", 98-321.

3 Key works for studying various aspects of the medieval history of Zadar are: Nada Klaić, Ivo Petricioli, Prošlost Zadra II. Povijest Zadra u srednjem vijeku do 1409. [The History of Zadar II: The History of Zadar in the Middle Ages before 1409] (Zadar: Filozofski fakultet, 1976). Tomislav Raukar offers a detailed analysis of the economic and social development in the municipality of Zadar in his works: "Zadarska trgovina solju u XIV. i XV. stoljeću" [Salt Trade in Zadar in the Fourteenth and Fifteenth Centuries], in: Studije o Dalmaciji u srednjem vijeku (odabrane studije) [Studies on Dalmatia in the Middle Ages (selected studies)] (Split: Književni krug, 2007), 297-356; Zadar u XV stoljeću. Ekonomski razvoj i društveni odnosi [Zadar in the Fifteenth Century. Economic Development and Social Relations] (Zagreb: Sveučilište, Centar za povijesne znanosti, Odjel za hrvatsku povijest, 1977). Irena Benyovsky Latin and Sandra Begonja published a very valuable study on urban space in the context of the prices and descriptions of real estate: "Nekretnine u notarskim dokumentima 13. stoljeća: primjeri dalmatinskih gradova (Zadra, Šibenika, Trogira, Splita i Dubrovnika)" [Real Estate in 13th-Century Notarial Documents: Case Studies of Dalmatian Cities (Zadar, Šibenik, Trogir, Split, and Dubrovnik)], Povijesni prilozi 51 (2016): 7-39. For the merchants of Zadar see Sabine Florence Fabijanec: "Društvena i kulturna uloga zadarskog trgovca u XIV. i XV. stoljeću" [Social and Cultural Role of Zaratin Merchant in the Fourteenth and the Fifteenth Centuries], Zbornik Odsjeka povijesnih znanosti Zavoda za povijesne i društvene znanosti HAZU 22 (2004): 55-120; "Dva trgovačka inventara kao pokazatelji ekonomskog i kulturnog života u Zadru u XIV. stoljeću" [Two Inventories of Merchants as Indicators of Economic and Cultural Life of Fourtheenth Century Zadar], Povijesni prilozi 25 (2003): 93-131; "Pojava profesije mercator i podrijetlo trgovaca u Zadru u XIV. i početkom XV. stoljeća" [Evolving of the Professional Position of a Mercator and the Origin of the Merchants in Zadar in the Fourteenth and at the Beginning of the Fifteenth Century], Zbornik Odsjeka povijesnih znanosti Zavoda za povijesne i društvene znanosti HAZU 19 (2001): 83-125, etc. For the notaries of Zadar see Branka Grbavac: "Zadarski notari u 13. i 14. stoljeću" [Zaratin Notaries in the Thirteenth and the Fourteenth Century] (magistarski rad, Sveučilište u Zagrebu, 2006); "Svakodnevni život notara u jednoj kasnosrednjovjekovnoj dalmatinskoj komuni - primjer Zadra" [Everyday Life of Notaries in a Late Medieval Dalmatian Commune: the Example of Zadar], Stara hrvatska svakodnevnica, in: Kolo. Časopis Matice hrvatske, ed. Vlado Bogišić (Zagreb: Matica hrvatska, 2006), 161-177.

4 A short description of the published and unpublished notary material of Zadar can be found in Anita Bartulović, "Prilog životopisu zadarskoga bilježnika Petra Perencana (1365. - 1392.)" [Addition to the Biography of Petrus Perençanus, Notary from Zadar (1365-1392)], Povijesni prilozi 50 (2016): 49-51. 
The formulaic nature of notary records rarely reveals any details of everyday life, which is understandable considering the nature of legal discourse, which largely stems from the field of property law and the law of obligations. ${ }^{5}$ Unlike these, court records offer more vivid details of everyday life due to the nature of individual legal cases from the field of criminal and procedural law. ${ }^{6}$ However, these documents in their form also generally follow medieval legal logic, where it was crucial to resolve the dispute while adhering to the deadlines and various procedural actions that would lead to the final verdict, which of course influenced the selective choice of details and information taken out of the context in which they had played out. ${ }^{7}$

Although court and notary records are characterized by selectivity of the information found in the formulaic statement, searching for vivid details of everyday life in notary records represents an additional challenge. Namely, the character of their legal discourse in the area of property law and the law of obligations does not in itself provide too much room for unusual details from everyday life in comparison to the character of the legal discourse of court records in the field of criminal and procedural law. Therefore, in our search for documents that reveal some details of the everyday life of an individual, at the core of this paper we placed unpublished documents from the notary registry of the Zadar notary Petrus, called Perençanus, son of the late Mr. Azon de Lemicetis from Padua (13651392). ${ }^{8}$ The analysis of these contracts will attempt to show how this information fits into the image of the medieval mentality, to what extent it compromises the formulaic nature of the statement, how this is reflected at the linguistic level in terms of deviations from the norms of medieval Latin, and whether these deviations were a result of the spoken discourse as used by the contractors themselves.

5 For individual branches of law see Lujo Margetić: Srednjovjekovno hrvatsko pravo - stvarna prava [Croatian Medieval Law: Property Law] (Zagreb; Rijeka: Pravni fakultet Zagreb; Pravni fakultet u Rijeci, 1983); Hrvatsko srednjovjekovno pravo - obvezno pravo [Croatian Medieval Law: Law of Obligations] (Zagreb; Rijeka: HAZU; Pravni fakultet Sveučilišta u Rijeci, 1997); Hrvatsko srednjovjekovno obiteljsko i nasljedno pravo [Croatian Medieval Family and Hereditary Law] (Zagreb: Narodne novine, 1996).

6 E.g. see the case from medieval Dubrovnik analyzed by Zdenka Janeković-Römer, Maruša ili suđenje ljubavi. Bračno-ljubavna priča iz srednjovjekovnog Dubrovnika [Marussa or the Trial of Love: A MaritalLove Story from the Medieval Dubrovnik] (Zagreb: Algoritam, 2007).

7 For more on that see: Tomislav Popić, Krojenje pravde. Zadarsko sudstvo u srednjem vijeku (1358. 1458.) [Tailoring Justice: Zadar's Judiciary in the Middle Ages (1358 - 1458)] (Zagreb: Plejada, 2014), 15-32. An analysis of court records in Zadar (Hrvatska (hereafter: HR) - Državni arhiv u Zadru, Zadar (hereafter: DAZD) - fond 22 - Curia maior civilium (hereafter: CMC)) Popić, Krojenje pravde, 22 showed that the selective choice of information was not limited to court records of Zadar, but that this happened in other European cities as well.

8 His notary records are referenced HR - DAZD - fond 31 - Bilježnici Zadra (hereafter: BZ), Petrus Perençanus (hereafter: PP). For more on that archive see: Anita Bartulović, "Paleografska, diplomatička i filološka analiza spisa zadarskoga notara Petra Perencana (1361. - 1392.) [Palaeographic, Diplomatic and Philological Analysis of Files of Petrus Perençanus, a Notary from Zadar (1361 - 1392)"] (hereafter: "PDFA") (doktorski rad, Sveučilište u Zagrebu, 2014). For the notary himself see: Bartulović, "Prilog životopisu zadarskoga bilježnika Petra Perencana (1365. - 1392.)”, 49-69. 


\section{Unusual details from notary records and their social context}

Taking into account the scope of Perençanus' notary records, a total of four boxes with 4330 folios and approximately 4983 contracts, ${ }^{9}$ the number of recorded details (49) from the personal life of the contractors is not so large since most of the registry is damaged and was unavailable for a thorough analysis ${ }^{10}$ and since such details are completely irrelevant for most contracts, which mostly have to do with the law of obligations, property law, family law and hereditary law.

These details can be observed through the lens of more or less common circumstances, events, situations, actions or attitudes and through the lens of socially unacceptable forms of behaviour in the everyday life of the Middle Ages. The first group of details would deal with the information about fires, illnesses, the possibility of mistaken identity, the buying of serves, the role of women in public life, the expression of emotions, and the agreement not to go to taverns on workdays, and the second with details on one's stay in prison, various complaints, illegitimate children, reasons for rejecting one's father's possessions, contractual obligations of a groom to pay a fine if it is established that he is already married, and, finally, a claim about the conclusion of marriage.

We shall start with the details that fall into the category of general occurrences in everyday life (fire, disease, plague epidemics, the establishing of one's identity) and which are worthy of attention due to their implications on the cause that led to the drawing up of the contract.

Information about fire was recorded in two contracts. ${ }^{11}$ In the first one (Carta emptionis), the saleswoman Jelena, widow of Gregorius Tolsich from Šibenik, a habitator of Zadar, feels the need to draw up a new contract because the old one perished in fire (when the Venetians burned the town of Šibenik down) in order to avoid punishment in the afterlife should the buyer, Maria, the widow of Andreas from Šibenik, fall victim to fraud. ${ }^{12}$ In the second contract (Carta finis), the Zadar nobleman Georgius de Soppe completely releases Georgius, son of the late Radossius, from the responsibility for an unintentional fire in which the nobleman's house on Ugljan burnt down. ${ }^{13}$ Both contracts have a religious background. Namely, both contractors hope for a better afterlife ${ }^{14}$ because they

\footnotetext{
9 Numerical information was taken from Bartulović, "PDFA", 22.

10 For the extent of damage see: Bartulović, "PDFA", 21.

11 There is another contract in which the fire is mentioned, but Perençanus crossed out that part in: HR-

DAZD-31-BZ, PP, b. 1, fasc. 7, fol. 7v-8r.

${ }^{12}$ HR-DAZD-31-BZ, PP, b. 3, fasc. 11, fol. 62r-62v.

${ }^{13}$ HR-DAZD-31-BZ, PP, b. 1, fasc. 14, fol. 58r.

${ }^{14}$ For the medieval understanding of the afterlife see: Robert Fossier, Das Leben im Mittelalter (aus dem Französischen von Michael Bayer, Enrico Heinenmann und Reiner Pfleiderer, München; Zürich: Piper Verlag GmbH, 2008), 446-491; Jacques Le Goff, Wucherzins und Höllenqualen. Ökonomie und Religion im Mittelalter, aus dem Französischen von Matthias Rüb (Stuttgart: Klett-Cotta, 2008); Zdenka Janeko-
} 
have consciously done their best to avoid sin. The first would be ignoring the first contract that was destroyed by fire, and the second not releasing somebody from the responsibility for an unintentional fire.

Everyday life in the Middle Ages was marked by a high mortality rate which was caused by a variety of factors, ranging from poor hygienic conditions and various pollutants to epidemics of disease and inadequate health care, considering the then reach of medicine, fettered with the ideological framework of ecclesiastical teachings, etc. ${ }^{15}$ In Perençanus's notary records, disease is never explicitly mentioned, only physical weakness as a reason for drawing up a written will or that the testator lay in bed when he declared his or her last will and testament orally. ${ }^{16}$ Only in one will was it explicitly stated that the reason for drawing up the will was the rampant plague. ${ }^{17}$ In addition, there is a mention of the treatment of a leg in a contract, when Rada arranged an apprentice's service for her son Charinus, son of the late Sladislavus, with the goldsmith Miroius, son of the late Disislavus, who was ready to lend a gold florin for the treatment of the apprentice's leg. ${ }^{18}$

Now we come to two contracts that mention the problem of identifying a person, that is to say, a possible mistaken identity. In the first one, the Zadar nobleman Christoforus de Lomesso vows to return the bequest of 80 livres of small dinars to the executioners of the will of the late Vochsa called Preçina, a former habitator

vić-Römer, "Na razmeđu ovog i onog svijeta. Prožimanje pojavnog i transcedentalnog u dubrovačkim oporukama kasnoga srednjeg vijeka" [Between the Earthly and Eternal Life: The Permeation of Material and Transcendental Images in the Testaments of the Citizens of Dubrovnik in the Late Middle Ages], Otium 2 (1994), no. 3-4: 3-15, etc.

${ }^{15}$ For disease and medicine in the Middle Ages in general and the attitudes about these see: Jacques Le Goff, Nicholas Truong, Die Geschichte des Körpers im Mittelalter (aus dem Französischen von Renate Warttmann, Stuttgart: Klett-Cotta, 2007), 115-133; Robert Fossier, Das Leben im Mittelalter, 28-46. For hygiene and various pollutants and the measures undertaken by Dalmatian communes and the problems they dealt with see: Sabine Florence Fabijanec, "Hygiene and Commerce: the Example of Dalmatian Lazarettos from the Fourteenth until the Sixteenth Century", Ekonomska i ekohistorija : časopis za gospodarsku povijest i povijest okoliša 4 (2008), no. 1: 115-133; Irena Latin Benyovsky, Srednjovjekovni Trogir: prostor i društvo [Medieval Trogir: Space and Society] (Zagreb: Hrvatski institut za povijest, 2009), 88-93; Danko Delić, "Proclamationes šibenskoga kneza Fantina de Cha de Pesaro (1441. - 1443.)" [Proclamationes of the Šibenik Duke Fantino de Cha de Pesaro (1441-1443)], Povijesni prilozi 35 (2008): $152,153,158,161,169$. For more on the epidemic of the plague and the relevant literature see Gordan Ravančić: "Prilog proučavanju Crne smrti u dalmatinskom gradu (1348. - 1353.) - raspon izvorne građe i stanje istraženosti na primjerima Dubrovnika, Splita i Zadra" [The Black Death in Dalmatian Towns Dubrovnik, Split and Zadar (1348-1353): Available Archival Sources and Current State of Research], Povijesni prilozi 26 (2004): 7-18; "Historiografija o epidemiji Crne smrti" [Historiography about the Mid-fourteenth Century Black Death Epidemic], Povijesni prilozi 33 (2007): 195-214.

${ }^{16}$ For the references for all written (91) and oral (7) wills from the Perençanus' registry see: "PDFA", 143-148. For more on the reasons for drawing up wills see: Zoran Ladić, "O razlozima sastavljanja kasnosrednjovjekovnih dalmatinskih oporuka” [Regarding Reasons for Compiling Late Medieval Dalmatian Last Wills"], in: Raukarov Zbornik. Zbornik u čast Tomislava Raukara, ed. Neven Budak (Zagreb: FF Press, 2005), 607-623.

${ }_{17}$ HR-DAZD-31-BZ, PP, b. 1, fasc. 5, fol. 7v (it was a copy of a will from 1361 made in 1367).

${ }^{18}$ HR-DAZD-31-BZ, PP, b. 1, fasc. 6, fol. 1r. 
of Zadar, to the Zadar noblemen Iohannes de Petriço and Damianus de Chalcina, at the request of Stoislava, the recipient of the bequest, if it is established that she is not the deceased's sister. ${ }^{19}$ Then, in the second contract, which follows immediately after the first one, Iuray called Scormagnich son of the late Dissinus, who lives in Omiš, releases the aforementioned nobleman from the obligation to return the bequest, but does not explicitly state the reason mentioned before. ${ }^{20}$ The question arises as to the relationship between Stoislava and Juray from Omiš and how it was possible for a case of mistaken identity to occur in a very small community such as the Zadar Commune, where almost everybody knew each other. Since neither the first nor the second contract provides enough information, it is quite possible that Stoislava married Juray from Omiš quite young, and for that reason there was a possibility that a dispute over her identity might arise if anyone wanted to dispute whether the bequest was given to the right person. The problem of identifying people was further exacerbated by the fact that there were no systematic or accurate censuses of the population, ${ }^{21}$ as well as no systematic keeping of birth, baptism or marriage records, which became regular only after a decree of the Council of Trent (1545-1563). ${ }^{22}$ The identification system itself was based on public opinion, as was stated in one of the provisions of the Statute: "If it is publicly claimed that someone is someone's son or daughter, there is no need to demand any kind of evidence before the lord dux or the Court. We also state the same about nephews and blood relatives." 23 Vivid examples of such practice of identification are numerous testimonies of witnesses about the relations between the deceased and those who sought their legacy in civil lawsuits in Zadar after the plague $1351-1353 .{ }^{24}$

As for the position of women, according to the provisions of the Statute, regardless of the medieval particularism of legal jurisdictions, they enjoyed certain legal

\footnotetext{
${ }^{19}$ HR-DAZD-31-BZ, PP, b. 1, fasc. 16, fol. 24v.

${ }^{20}$ HR-DAZD-31-BZ, PP, b. 1, fasc. 16, fol. 24v-25r.

${ }^{21}$ For the problem of censuses see: Tomislav Raukar, Studije o Dalmaciji u srednjem vijeku, 85-91; Domagoj Madunić, "Mjera grada. Zadarski popis stanovništva 1527. godine" [Measure of the City: The 1527 Zadar Census], Povijesni prilozi 36 (2009): 23-63.

${ }^{22}$ A condensed overview of the history of record keeping can be found in Ante Šupuk, "Šibenski Liber baptizatorum (1581 - 1590), njegova antroponimna građa i osobitosti te antroponimije" [The 'Liber baptisatorum' of Šibenik (1581-1590), its Anthroponymous Material and the Specificities of This Anthroponymy], Radovi 7 (1975): 83-84.

${ }^{23}$ Josip Kolanović, Mate Križman, ed., Zadarski statut: sa svim reformacijama odnosno novim uredbama donesenim do godine 1563. [Statut of Zadar with all Reformations, i.e. New Regulations till 1563] (hereafter: ZS) (Zadar; Zagreb: Ogranak Matice hrvatske; Hrvatski državni arhiv, 1997), book III, chapter 103.

${ }^{24}$ See Gordan Ravančić, "Curia maior ciuilium - najstariji sačuvani registar građanskih parnica srednjovjekovnog Zadra (1351.-1353.)” [Curia Maior Ciuilium: The Oldest Preserved Register of Civil Court Cases in Medieval Zadar (1351-1353)], Radovi Zavoda povijesnih znanosti HAZU u Zadru 43 (2001): 85-160.
} 
protection and had limited legal capacity. ${ }^{25}$ In Perençanus's writings, women from all social strata and ethnic origin often had the role of a contractor. Most of them were married women or widows, who enjoyed greater autonomy in performing legal business. The reason to appoint a procurator, mentioned by the appointer Mariça, the widow of Rambaldinus de Saladinis, illustrated this limited legal capacity: cum ipsa sit femina et non licet dominabus per curias ambullare et in iuditio adesse. ${ }^{26}$ In this only recorded statement in the entire Perençanus's registry, where there is mention of many procurators that had been appointed by women, we can see a noblewoman protesting, dissatisfied by the limitations imposed on her by society. This reason is not stated in the contract of her procurator, specifically authorized to reject the role of executrix on her behalf, entrusted to her by her late husband in his will, to be carried out together with his three brothers. ${ }^{27}$

Let us continue exploring the position of women in the society of medieval Zadar. In Perençanus's registry, there are four contracts for buying serves. ${ }^{28}$ The first two contain features of service contracts, and the other two of purchase contracts. ${ }^{29}$ The contracts containing features of service contracts also include the promise of the buyer that he will set his serves free after ten and twelve years respectively, in-

${ }^{25}$ For the legal position of women in individual Dalmatian communes see: Vilma Pezelj, "Naznake pravnog položaja žene u srednjovjekovnom Zadru" [Characteristicas of the Legal Position of Women in Medieval Zadar], Zbornik radova Pravnog fakulteta u Splitu 43 (2006), no. 3-4: 523-551; Ibid, "Neki elementi pravnog položaja žene u rapskom statutu iz 14. stoljeća" [Some Elements of the Legal Position of Women in the Rab Statute of the 14th Century], Zbornik radova Pravnog fakulteta $u$ Splitu 48 (2011), no. 1: 73-87; Vilma Pezelj, Marija Štambuk Šunjić, "Pravni položaj žene prema lastovskom statutu iz 1310. godine" [Legal Position of Women in the Medieval City of Lastovo 1310.], Zbornik radova Pravnog fakulteta u Splitu 50 (2013), no. 3: 525-539; Marija Mogorović Crljenko, “Žena u obitelji i društvu - prema odredbama Motovunskog statuta" [Woman in Family and Society: According to the Provisions of the Statute of Motovun], Vjesnik Istarskog arhiva 8-10 (2003): 203-212; Zdenka JanekovićRömer, Rod i grad. Dubrovačka obitelj od XIII do XV stoljeća [The Lineage and the City: The Family in Dubrovnik from 13th to 15th Century] (Dubrovnik: Zavod za povijesne znanosti HAZU u Dubrovniku, 1994), 77-93, 126-128, 130-137; Sabine Florence Fabijanec, "Gospodarska djelatnost žena u dalmatinskom komunalnom području od XIV. do XVI. stoljeća” [The Economic Activity of Women in the Dalmatian Communal Area from the Fourteenth to the Sixteenth Century], in: Ženske skozi zgodovino. Zbornik referatov 32. zborovanja slovenskih zgodovinarjev, ed. Aleksandar Žižek (Celje: Zveza zgodovinskih društev Slovenije, 2004), 49-64 etc. For the process of gradual elimination of women in hereditary law see: Zrinka Nikolić Jakus, “Obitelj dalmatinskog plemstva od 12. do 14. stoljeća” [Noble Families in Dalmatia from the Twelfth through the Fourteenth Centuries], Acta Histriae 16 (2008), 1-2: 61-69.

${ }^{26}$ HR-DAZD-31-BZ, PP, b. 1, fasc. 8, fol. 1r.

27 HR-DAZD-31-BZ, PP, b. 1, fasc. 8, fol. 4r.

${ }^{28}$ For the issue of serves see Neven Budak: "Oslobađanje serva i ancilla i napuštanje upotrebe njihove radne snage na istočnom Jadranu" [Liberating servi and ancillae and Abandoning the Use of Their Labour on the East Adriatic Coast], Historijski zbornik 38 (1985): 115-130; "Pravni položaj serva i famula u komunalnim društvima na istočnom Jadranu" [The Legal Status of Servi and Famuli in the Communal Societies on the East Adriatic Coast], Radovi Instituta za hrvatsku povijest 19 (1986): 51-68; "Slavery in Late Medieval Dalmatia/Croatia: Labour, Legal Status, Integration”, Mélanges de l'école française de Rome. Moyen Âge, 112 (2000): 745-760 etc.

${ }^{29}$ HR-DAZD-31-BZ, PP, b. 1, fasc. 3, fol. 22r-22v, 33r-33v, fasc. 5, fol. 53v-54r, fasc. 7, fol. 18r. For the differences in their titles and their diplomatic structure see: "PDFA", 76, 102-103. 
voking the act of mercy. The other two contracts do not contain such a release clause, but one stipulating that the buyers have the right to the serves' descendants as well. Does the structure of the contracts have any connection to the ancestry of the serves and/or their religion? ${ }^{30}$ In the first two contracts, the buyers are textile merchants Michouelus, son of the late Draxilius and Lukas, son of the late Leo, and the serves are from Bosnia (Milaça and Theuertcha). They bought the serves by means of a third party (cum Michouelus draperius condam Draxilii de Iadra alias comixisset Vlathecho Morolacho condam Vglisse de chatono Debolocich; cum Lucas draperius condam Leonis de Iadra alias comixisset Stancho vicario condam Stoislaue de Iadra). It is interesting to note that Morlach ${ }^{31}$ Vlathechus bought the serva Milaça from the Bosnian Duke of Vukac Hrvatinić, the father of Hrvoje Vukčić Hrvatinić, of whom not a lot of information has survived. ${ }^{32}$ In the other two contracts, the purchase of a serve was performed without a middleman. The famous banker Peter from Florence ${ }^{33}$ bought a female serva from Nicola de Lovato from Genoa, and Helena, the widow of Laurentius de Çambonino, the former ciuis Iadre, from the Vlach Dichoe, son of Mirosus. The serves are a Christianized fifteen-year-old Tatar girl named Lucia and Bosnian-born Christianized thirtyyear-old mother Bogoslava and her fourteen-year-old daughter Çoia. These were most probably former members of the heretic Bosnian Church, ${ }^{34}$ while the serves from the first two contracts were Christian women. Was the fact that these Christianized serves were former members of another religion the reason why

\footnotetext{
${ }^{30}$ Sally McKee, "Domestic Slavery in Renaissance Italy", Slavery and Abolition 29 (2008), no. 3: 313, confirms the importance of slaves with examples from court practice.

${ }^{31}$ For the problem of Vlachs and Morlachs in Croatian historiography see: Zef Mirdita, Vlasi $u$ historiografiji [Vlachs in the Historiography] (Zagreb: Hrvatski institut za povijest, 2004), 267-348; Ivan Botica, "Vlah i vlah - nekoć i danas" [The Present and Past - Vlach and vlach], in: Jezik i identiteti, ed. Jagoda Granić (Zagreb; Split: Hrvatsko društvo za primijenjenu lingvistiku, 2007), 61-69; Ivan Botica, "Prilog istraživanju najstarijega spomena vlaškoga imena u hrvatskoj historiografiji" ["Contribution to Research of the Oldest Record of the Name Vlach in Croatian Historiography"], Radovi 37 (2005): 3546; Gordan Ravančić, "Neka razmišljanja o prvome spomenu Vlaha" [Some Speculations about the First Mention of Vlachs in the Croatian Sources], in: Poeta nascitur, historicus fit - ad honorem Zef Mirdita, ed. Albert Ramaj (St. Gallen; Zagreb: Albanisches Institut; Hrvatski institut za povijest, 2013), 115-124.

${ }^{32}$ For Vukac Hrvatinić see: Pejo Ćošković, "Hrvatinići” [Hrvatinići], Hrvatski biografski leksikon (online), Leksikografski zavod "Miroslav Krleža", http://www.enciklopedija.hr/natuknica.aspx?id=26389, http://hbl.lzmk.hr/clanak.aspx?id=89 (accessed on 23 February 2018); Ferdo Šišić, Vojvoda Hrvoje Vukčić Hrvatinić i njegovo doba (1350. - 1416.) [Duke Hrvoje Vukčić Hrvatinić and His Times (13501416)] (Samobor; Zagreb: A. G. Matoš; Naklad Hrvoje, 2004. (pretisak izdanja iz 1902)), 9, 11, 14, 17, $18,20$.

${ }^{33}$ For Peter, the banker from Florence see: Tomislav Raukar, Studije o Dalmaciji u srednjem vijeku, 62-64.

${ }^{34}$ For the Bosnian Church see: Franjo Šanjek, Bosansko-humski krstjani i katarsko-dualistički pokret u srednjem vijeku [Krstjani from Bosnia and Hum and the Cathar-dualistic Movement in the Middle Ages] (Zagreb: Kršćanska sadašnjost, 1975); Fenomen "krstjani" u srednjovjekovnoj Bosni i Humu. Zbornik radova [Krstjani in Medieval Bosnia and Hum, Conference Proceedings], ed. Franjo Šanjek (Sarajevo; Zagreb: Institut za istoriju; Hrvatski institut za povijest, 2005); Noel Malcolm, Povijest Bosne [The History of Bosnia] (Zagreb; Sarajevo: Erasmus Gilda, Novi Liber; Dani, 1995), 37-56 (see also the literature referenced by the author).
} 
they were in a worse social position than Christian women when the contracts in which they were treated as movable property were signed? Was this the reason why their price was lower (the price for Bogoslava and Çoia was 80 livres of small dinars, which is about 16 ducats, while the price for Milaça was 16 gold ducats and for Theuertcha 60 livres of small dinars, which is about 12 ducats)? Were the local well-off people more God-fearing than the inhabitants of Zadar of foreign origins? This is difficult to determine on such a small sample of contracts. The position of the papacy, which tolerated the continuation of slavery of those who converted to Christianity, but not of those who were Christians before they were enslaved, ${ }^{35}$ could have contributed to the difference in their position, which is confirmed by the fact that different kinds of contracts were signed. In any case, these different contracts show the clash between the growing influence of the Church which opposed human trafficking, ${ }^{36}$ and the legal regulations on the position of serves who had limited legal capacity. ${ }^{37}$

As for the emotional life of the contractor, sometimes one can come across brief expressions of emotions quite unexpectedly, usually in deeds of donation. In the formula causa, ${ }^{38}$ in 11 of the 47 preserved deeds of donation, feelings of love towards their next of kin (their children, granddaughter, deceased wife, deceased members of their families) or God as the reason why they decided to give their possessions away were listed..$^{39}$ In the two further deeds, a fear of God or a fear that the donator would consciously burden his soul with sin by failing to execute the testator's last will was listed as the reason for the donation..$^{40}$

\footnotetext{
${ }^{35}$ McKee, "Domestic Slavery", 313.

${ }^{36}$ For more on that see: Neven Budak, "Trgovina radnom snagom na istočnom Jadranu - razvoj i značaj" [Labour Trafficking on the East Adriatic Coast: Its Development and Importance], Historijski zbornik 37 (1984): 107.

${ }_{37}$ ZS, book II, chapter 25, book III, chapters 5, 21, 131, book V, chapter 13.

${ }^{38}$ For the diplomatic structure of individual notary documents see: Grbavac, "Notarijat", 98-321.

${ }^{39}$... deum pre oculis habens et amore dulcissimo paterno astrictus dedit, donauit et transactauit post mortem eius dilectis filiis suis; ... nolens ingratam esse et in peccato ingratitudinis persistere, set beneficia, seruicia et munera quam plurima et infinita a dicta domina Mandiça, nepte sua, habita et percepta; ... ex feruenti amore, quem prefactus ser Stephanus habuit erga dominam Iacobinam, olim vxorem suam; ... ob reuerenciam omnipotentis Dei et gloriose Virginis Marie, matris eius, et tocius curie celestis et pro anima sua et suorum mortuorum ac in remissione omnium suorum peccatorum; Cum Petrus condam ser Vulcine de Sloradis de Iadra cum tota et integra mente sua et puro corde efficialiter datus sit ac penitus vellit omnino Deo seruire et religionem intrare volens mondana spernere et derelinquere pro aquirendo vitam celestialem, que perpetua est. The references for these quotes can be found in: "PDFA", 87. Unlike these five deeds of donation in which the feelings were expressed in greater detail, in the other six deeds only a short prepositional phrase of ex feruenti amore can be found (HR-DAZD-31-BZ, PP, b. 2, fasc. 1, fol. $7 \mathrm{v}, 36 \mathrm{v}$; b. 3, fasc. 10, fol. 25v, fasc. 11, fol. 22r, 41r; b. 4, fasc. 12, fol. 1v).

${ }^{40}$... nolens veritatem ocultare, et animam suam a pecatis grauare, deumque timens (HR-DAZD-31-BZ, PP, b. 1, fasc. 11, fol. 12v); ... ex bona consciencia et çelu charitatiuo ductus et cum animo mero, puro, quieto et sincero nolens in alio seculo animam suam grauare, set in eius vita debitam supradictam satisfacere (HR-DAZD-31-BZ, PP, b. 2, fasc. 4, fol. 37r).
} 
A quite unexpected document is the one in which in early 1381 the executors of the will Marcheta, the widow of Iohannes de Calcina and the deceased's illegitimate son Domulus, following the deceased's instructions, return the house to Iohannes de Fumadis, which the deceased had admitted to appropriating from his grandfather Marinus de Fumadis by fraud. ${ }^{41}$ The opportunity for this obviously presented itself when he officially became one of the executors of the will of the late Iohannes in $1366 .{ }^{42}$ Prior to his death, the testator wanted to rectify the situation in order to secure himself a peaceful departure to the other world. Here we find the same religious component as in the two deeds mentioned previously or in the two contracts in which fire was mentioned. The only difference being that here the testator did commit a sin deliberately at one point of his life, and he wanted to rectify it on his deathbed. But there is something else in that contract which attracts attention. Considering the fact that the will was made on 27 June 1370 , and that shortly afterwards the testator died because on 28 August 1370 a certificate on the inventory of his goods was issued, ${ }^{43}$ from the contract itself it is unclear why the executors, together with Fr. Marinus from Krk, also an executor of the will who had died in the meantime, waited eleven years to fulfil the deceased's wish. There were probably many legal disputes over that property, and these could have been the reason why the executors waited so long to fulfil the testator's instructions. Supporting this is the only surviving dispute over the property, completed in April $1373 .{ }^{44}$

A very unusual contract is the one with the title Carta conuentionis inter Laurencium cimatorem et Bartolomeum peliparium. ${ }^{45}$ Namely, the subject of this contract is an agreement between Laurencius, a cloth shearer from Venice and a habitator of Zadar, and Bartolomeus, a furrier from Zadar, that they would not go to taverns on workdays for the next year. ${ }^{46}$ The reason why these two "merry men" felt the need to sign such an agreement remains unknown.

\footnotetext{
${ }^{41}$ Tadija Smičiklas et al., ed., Codex diplomaticus Regni Croatiae, Dalmatiae et Slavoniae (hereafter: CD) 16 (Zagreb: JAZU, 1976), doc. 132, 145-147 (the receipt has not survived in the registry). For similar wills from the fifteenth century in which testators of noble origins admit to various abuse of power in the Republic of Ragusa see: Zdenka Janeković-Römer, Okvir slobode. Dubrovačka vlastela između srednjovjekovlja i humanizma [The Frame of Freedom: The Patriciate of Ragusa (Dubrovnik) between the Middle Ages and Humanism] (Zagreb; Dubrovnik: Zavod za povijesne znanosti HAZU u Dubrovniku, 1999), 170-171.

${ }^{42}$ HR-DAZD-22-CMC, kut. 3, fasc. 2, fol. 186v.

${ }^{43}$ HR-DAZD-31-BZ, PP, b. 1, fasc. 14, fol. 16r.

${ }^{44}$ HR-DAZD-22-CMC, kut. 4, fasc. 4/1, fol. 33r. For the degree to which the court records of Zadar have been preserved see: Popić, Krojenje pravde, 33-35.

${ }^{45}$ HR-DAZD-31-BZ, PP, b. 1, fasc. 1, fol. 8r.

${ }^{46}$ Gordan Ravančić brings a study on medieval taverns in Dubrovnik in: Život u krčmama srednjovjekovnog Dubrovnika [Lifes in Taverns in Medieval Dubrovnik] (Zagreb: Hrvatski institut za povijest; Dom i svijet, 2001); "Kvantifikacija svakodnevnice - primjer dubrovačkih krčmi" [Quantification of Daily Life: The Example of Dubrovnik Taverns], Povijesni prilozi 39 (2010): 11-21.
} 
Now we move on to details of everyday life which were more or less condemned by society and which resulted in some form of legal sanction or public condemnation.

One of the forms of legal sanction was imprisonment. ${ }^{47}$ Occasionally, service contracts included a clause stipulating that the master had the right to enslave his apprentice in the event that he escaped. ${ }^{48}$ Three contracts state that the reason for the legal transaction (contracting of service, obligation, sale) is the payment of the debt due to which the debtor was imprisoned because he could not repay it. In the first and second contract (from 1373 and 1377 respectively), it is stated that Yuanes, a blacksmith and son of the late Pribislavus and Georgius, son of Yuanes, habitatores of Zadar, were imprisoned for failing to repay their debts. ${ }^{49}$ The practice of imprisoning insolvent debtors was intended to force the debtor to repay his debt, and was by no means a substitute for the fulfilment of their obligation, ${ }^{50}$ i.e. prison was a means of fiscal coercion. ${ }^{51}$ The Zadar Statute expressly states: "We declare that anyone who cannot repay money he has taken from the lender be arrested by the order of the dux and the court, detained and taken to the fort to remain there until they repay their whole debt in full." ${ }^{2}$ The third contract does not specify the circumstances under which Jakobus, a cobbler, son of the late Matheus, a cobbler from Zadar, was imprisoned in Venice. With his consent, his mother Stana and wife Margarita sold their house in 1386 in order to get him out of prison. ${ }^{53}$ It is possible that he was also imprisoned due to a debt, judging by the provisions of the Zadar Statute, stipulating that a fugitive foreigner can be arrested for a debt and can be brought before the dux and the Court, ${ }^{54}$ in accordance with the contracts and agreements that the Zadar Commune had with other Dalmatian communes and other cities. ${ }^{55}$ In this context, we can also view the document titled Carta contemptationis vnius casselle cum auro, argento, perlis, lapidibus preciosis et aliis rebus in ea existentibus. ${ }^{56}$ In it enslaved people from Kotor are mentioned. The document in question is a receipt issued by the Zadar nobleman

\footnotetext{
${ }^{47}$ For the primary roles of prisons through various historical periods in individual Dalmatian communes see: Željko Radić, "Zatvor u srednjovjekovnom trogirskom pravu” [Prison in the Medieval Law of Trogir], Hrvatski ljetopis za kazneno pravo i praksu 12 (2005), no. 1: 89-107; Ivana Jaramaz-Reskušić, Kaznenopravni sustav u Šibeniku od 14. do 16. stoljeća [Penal System in Šibenik from 14th to 16th Century] (Šibenik: Gradska knjižnica "Juraj Šižgorić”, 1996), 193-205.

${ }^{48}$ HR-DAZD-31-BZ, PP, b. 1, fasc. 5, fol. 53v, fasc. 9, fol. 34v, fasc. 6, fol. 21v.

${ }^{49}$ HR-DAZD-31-BZ, PP, b. 2, fasc. 1, fol. 30r-30v, fasc. 5, fol. 22r.

${ }^{50}$ Radić, “Zatvor u srednjovjekovnom trogirskom pravu”, 99.

51 Jaramaz-Reskušić, Kaznenopravni sustav u Šibeniku, 200-201.

${ }^{52}$ ZS, book III, chapter 57.

${ }^{53}$ HR-DAZD-31-BZ, PP, b. 3, fasc. 12, fol. 2r-2v.

${ }^{54}$ ZS, book II, chapter 16 .

55 ZS, book II, chapter 8 .

${ }^{56}$ HR-DAZD-31-BZ, PP, b. 1, fasc. 3, fol. 11r.
} 
Nicolaus Galellus for the treasure chest given to him as deposit by the municipal procurators. He gave this chest to two Kotorans who were imprisoned on the request of the royal knight Jakobus de Varicassis, his brother Daniel, Simon de Botono and Franciscus de Çadulinis for a debt of 850 gold florins or ducats. From the content of the contract itself, it is not entirely clear what role the Zadar noblemen had, that is, how they were related to the imprisoned Kotorans, what kind of debt it was, considering the fact that that was a fairly large amount of money, or how it came about that the municipal procurators deposited the treasure chest in the first place. However, there is a statutory provision which offers a possible answer. This was most likely a confiscation of goods owned by a suspect debtor. ${ }^{57}$ According to the provisions of the Statute, the curia could issue an order to seize the debtor's property proportional to his debt at the request of the creditor (in this case of the four Zadar noblemen who lodged the request) and hand over this property to a third person for safe keeping (and that was Nicolaus Galellus). But how did the procurators acquire the chest? It can be assumed that this chest was confiscated from the Kotorans when they were arrested or that someone brought it later to pay for their debt. On that occasion, the procurators probably stored the chest in the municipal procuria, where apart from very important documents, valuable items were kept. ${ }^{58}$

Documents with the title Carta protestationis are most certainly a kind of introduction to court disputes. In them the injured party complains about the injustice they have suffered because of the breach of contractual obligations by the other party. Complaints in Perençanus's registry are very rare and as such are very interesting because they belong to the field of procedural law for breach of contractual obligations. In Perençanus's registry, a total of six complaints have been preserved (of which only two according to their title because they were not copied). The reasons for complaints are various, and they all come down to the fact that the injured parties feel that they have been deceived by having their rights denied in relation to a previous contract (in the first three contracts) or statutory provisions (in the last contract). The complaints refer to incomplete deliveries of farm animals, oil press which was not constructed, unauthorized appropriation of a part of a wall while building a house and unlawful eviction from land. ${ }^{59}$

Family relations provide a fertile ground for various scandals. In Perençanus's registry one can find mention of illegitimate children, ${ }^{60}$ murder in relation to the

57 ZS, book II, chapter 64. Cf: Ivan Beuc, "Statut zadarske komune iz 1305. godine" ["The Statute of the Commune of Zadar from 1305”], Vjesnik Državnog arhiva u Rijeci II (1954): 657-658.

${ }^{58}$ For the municipal treasuries in Dalmatian communes see: Serđo Dokoza, "Archivium comunis Jadre u XIV. stoljeću" [Archivium comunis Jadre in the 14th Century], Radovi Zavoda povijesnih znanosti HAZU u Zadru 48 (2006): 215-230.

${ }^{59}$ For the reference for all four contracts see: “PDFA", 153.

${ }^{60}$ For the general position of illegitimate children in Dalmatian communes see: Neven Budak, "Struktura i uloga obitelji serva i famula u komunalnim društvima na istočnom Jadranu" [The Structure and Role 
rejection of one's father's possessions, the possibility of bigamy ${ }^{61}$ and a dispute over whether or not a marriage was concluded under the rules of the Roman Catholic Church, which were obviously subject to public outrage in the Commune of Zadar. According to Decretum Gratiani of 1140, the Church condemned adultery committed by both men and women, but in reality this was only a theoretical standpoint. ${ }^{62}$ The nobility were as promiscuous as they had been in barbarous times, ${ }^{63}$ and merchants were no far behind. ${ }^{64}$ Thus, in Perençanus's register we find evidence of seven Zadar noblemen being mostly fathers of illegitimate children (three daughters and six sons), compared to two merchants and one habitator of Zadar of Croatian origin, his occupation not being mentioned, all of whom have one illegitimate child. According to the provisions of the Statute of Zadar, sons born out of wedlock in a relationship between two free people who married after the birth of the child were considered legitimate under the law. ${ }^{65}$ However, this was not the case with illegitimate children from the analyzed documents. Namely, for almost all the fathers of illegitimate children there are confirmations that they were married, and for some of them that these were their only children. ${ }^{66}$ Illegitimate

of the Family of Serves and Famulae in the Communal Societies on the East Adriatic Coast], Starohrvatska prosvjeta 14 (1984): 353-355; Janeković-Römer, Rod i grad, 108, 115-119; Janeković-Römer, Maruša, 183-184; Marija Karbić, "Što znamo o nezakonitoj djeci u gradskim naseljima u međurječju Save i Drave tijekom srednjeg vijeka?" [What do We Know about Illegitimate Children in Urban Settlements between the Sava and Drava Rivers during the Middle Ages?], Scrinia Slavonica 2 (2002): 168-177; Zdravka Jelaska, "Trogirska srednjovjekovna obitelj" [The Medieval Family in Trogir (13th-14th century)], Povijesni prilozi 18 (1999): 48-50; Zrinka Nikolić Jakus, Rođaci i bližnji. Dalmatinsko gradsko plemstvo u srednjem vijeku [Kin and Kith: Dalmatian Urban Nobility in the Early Middle Ages] (Zagreb: Matica hrvatska, 2003), 52-56 etc.

${ }^{61}$ For the Biblical and legal arguments in medieval canon law on bigamy see: John Witte, Jr, "Why Two in One Flesh? The Western Case for Monogamy over Polygamy", Emory Law Journal 64 (2015): 17111715. For prosecution in case of bigamy in the Middle Ages see: Sara McDougall, "Bigamy: A Male Crime in Medieval Europe?", Gender and History 22 (2010), no. 24: 30-46.

${ }^{62}$ Le Goff, Truonog, Die Geschichte des Körpers, 48.

${ }^{63}$ Ibid, 50.

${ }^{64}$ For a comparison of family life of merchants in connection with illegitimate children on both sides of the Adriatic see Fabijanec, "Društvena i kulturna uloga zadarskog trgovca", 93.

${ }^{65} \mathrm{ZS}$, book III, chapter 102.

${ }^{66}$ Thadeus de Sgagno married to Mariça had no children; Draga is the widow of Bogdanus, son of the late Yuannes, and for the time being it is unknown whether they had any children; Lucas, son of the late Leo had one daughter, Honesta and one daughter who had died from his first marriage, and with his second wife, Margarita, he had no children (for references for the three men see note 67). Iohannes de Calcina, Gale de Chande and Philippus de Begna only had illegitimate children, while Madius Galellus and Nicola de Çadulinis had illegitimate children along with legitimate children (for these noblemen see Serđo Dokoza, Zadarsko plemstvo [The Nobility of Zadar], forthcoming). There is no confirmation that Draxile was an illegitimate son of the textile merchant Michael, son of Draxilius, who was in turn a relative of the well-known Michovilus, son of the late Petrus, a textile merchant or some other Michovilus's cousin, judging by the information from the inventory of goods belonging to Michovilus (Jakov Stipišić, Inventar dobara Mihovila suknara pokojnog Petra iz godine 1385. [Inventory of Goods of a Textile Merchant in Zadar Michael, Son of the Late Peter, from 1385 ] (Zadar: Stalna izložba crkvene umjetnosti u Zadru, 2000). 
children are most often mentioned in documents which were drawn up before or after the death of their fathers. The children appear as recipients of bequests left to them in the wills of their fathers $(5)^{67}$ and as executors of their fathers' wills (3) ${ }^{68}$ Two illegitimate sons are mentioned as deceased next to the names of the executors of their wills. ${ }^{69}$ For two illegitimate sons, their fathers, noblemen of Zadar, made sure they got an apprenticeship. Thus, Madius, son of the late Nicolaus Galellus arranged an apprenticeship with a tailor for his illegitimate son Cressulus through a Carta famulatus contract, ${ }^{70}$ and Nicola de Çadulinis stated in his codicil that Damianus, a cloth shearer, be rewarded out of his land income, provided they agreed on teaching his illegitimate son Georgius. ${ }^{71}$ This was how fathers provided for their illegitimate sons, since they could not be included in the legitimate line of hereditary succession, that is to say, they could not inherit their father's possessions, which were reserved only for legitimate heirs. Thadeus de Sgagno, a nobleman from Zadar, had the most illegitimate children. In his will from 1368, he declared his wife Mariça a universal successor, and he also left 100 livres of small dinars to each of his underage children: a daughter and a son he had with a woman named Maria from Rab and daughter Chatarina he had with a woman named Bogdana. ${ }^{72}$ It could be assumed that Maria from Rab and Bogdana were his serves, considering the thesis that concubines were tolerated in the $\mathrm{Me}-$ diterranean ${ }^{73}$ as well as the fact that mothers of illegitimate children were almost always maids in the house of the father and that these children were members of the households of their fathers, who were predominantly noblemen. ${ }^{74}$ An interesting comparison can be made between the behaviour of Thadeus de Sgagno and the textile merchant Lucas, son of the late Leo, in terms of the stipulation in their wills on their wives' possible future wish to remarry. The nobleman seems to have been much more generous, because in that case he leaves his wife 800 livres of

${ }^{67}$ HR-DAZD-31-BZ, PP, b. 1, fasc. 10, fol. 33r-33v (a son and two daughters of Thadeus de Sgagno); b. II, fasc. 16, fol. 48v (Simona, pupilla filia Mire condam Domincii Ceperrach de Pago et filia naturalis condam Bogdani condam Yuanis, habitatoris Iadre); b. IV, fasc. 16 (3), fol. 4r (Pelegrinus filius naturalis Luce (sc. draperii) condam Leonis de Iadra).

${ }^{68}$ See note 41 (Domulus, the illegitimate son of Iohannes de Calcina); HR-DAZD-31-BZ, PP, b. 1, fasc. 14, fol. 6v (Domincha piçochara, filia naturalis condam Gale de Chande, olim ciuis Iadre), fasc. 14, fol. 9r-9v (Marinus, filius naturalis condam Philippi de Begna).

${ }^{69}$ HR-DAZD-31-BZ, PP, b. 1, fasc. 13, fol. 21v-22r (Gregorius, filius naturalis condam Mathei de Cotopagna Iadriensis; in an earlier document it doesn't say that he is an illegitimate son fasc. 9, fol. 41r), fasc. 14, fol. 16r-16v (Draxile merçarius condam filius naturalis Michaelis drapperii de Iadra).

${ }^{70}$ HR-DAZD-31-BZ, PP, b. 1, fasc. 17, fol. 19v. The grandfather Nicola also left a legacy to Madius' illegitimate son in his will from 1361 (HR-DAZD-31-BZ, PP, b. 1, fasc. 5, fol. 7r).

${ }^{71}$ HR-DAZD-31-BZ, PP, b. 1, fasc. 13, fol. 23r.

72 Cf. note 67.

${ }^{73}$ For the literature on that topic see: Budak, "Struktura i uloga obitelji serva i famula", 353.

${ }^{74}$ Janeković-Römer, Rod i grad, 48. 
small dinars, and the merchant Lucas doesn't leave his wife anything. ${ }^{75}$ Depending on his financial situation, the testator generally leaves legacies to members of the clergy or Church institutions for the salvation of his soul. ${ }^{76}$ In this regard, these "adulterers" do not differ from each other. The reasons for their extramarital affairs might have been various: dissatisfaction with an arranged marriage, ${ }^{77}$ which played a crucial role in securing economic and political interests, especially for the rich families, forbidden love that fell outside the preferred class endogamy, ${ }^{78}$ or the tendency of the individual towards promiscuity. Moreover, due to the high rate of child mortality, ${ }^{79}$ many men (Thadeus de Sgagno and Lucas, son of the late Leo exemplify this) were eager to secure male offspring out of wedlock, irrespective of the fact that such offspring could not be heirs to their father's possessions, but only recipients of bequeathed legacies. Namely, offspring of noblemen born out of wedlock in the late Middle Ages were not considered members of the genus ${ }^{80}$ under the influence of ecclesiastical law which emphasized the importance of the sacrament of marriage. ${ }^{81}$

The statutes guaranteed the legal protection of children, but in general the father had an unlimited right of disposal of his property. ${ }^{82}$ Statements on the rejection of inheritance are documents having to do with the regulation of inheritance rights if the heir believed that the right was detrimental to him, which is stated in a general clause. Usually, sons drew these up after the death of their fathers ${ }^{83}$ but one of these is different. Namely, a son declares that he renounces the goods belonging to his father who was banished from Zadar for the murder he had

\footnotetext{
${ }^{75}$ For the textile merchant Lucas, son of the late Leo and his son see: Fabijanec, "Profesionalna djelatnost zadarskih trgovaca u XIV. i XV. stoljeću" [Professional Life of Merchants from Zadar in the Fourteenth and the Fifteenth Century], Zbornik Odsjeka povijesnih znanosti Zavoda za povijesne i društvene znanosti HAZU 17 (1999): 43-48. Owing to the will of Lucas, son of the late Leo (see note 67), which was previously thought to have been lost (Fabijanec, "Profesionalna djelatnost", 48), it is clear that Pelegrinus is Leo's illegitimate son.

${ }^{76}$ For a more general study on this subject and the pertaining literature see: Zoran Ladić, Last Will: Passport to Heaven. Urban Last Wills from Late Medieval Dalmatia with special attention to the Legacies pro Remedio Animae and ad Pias Causas (Zagreb: Tiskara Zelina, 2012).

${ }^{77}$ Which is supported by the statutory provision of the Statute of Zadar, stipulating punishment for people who get married without their father's consent (book III, chapters 90, 116, 117).

${ }^{78}$ For how strictly the principle of endogamy was adhered to and what the position of illegitimate offspring over time was according to the provisions of city legislature of individual Dalmatian cities (Dubrovnik, Šibenik, Trogir and Kotor), see: Janeković-Römer, Okvir slobode, 69-71.

${ }^{79}$ For more on the influence of demographic factors on the structure of the family in communal societies see: Janeković-Römer, Rod i grad, 42-50.

${ }^{80}$ Janeković-Römer, Okvir slobode, 242. Contrary to that, in the eleventh century an illegitimate child was considered a member of the genus (Nikolić Jakus, Rođaci i bližnji, 55).

${ }^{81}$ Janeković-Römer, Rod i grad, 115-116.

${ }^{82}$ Janeković-Römer, Rod i grad, 103. From ZS the following provisions are related to the rights of children and parents: book II, chapters 17, 20, 23, 26, 27, 33; book III, chapters 12, 16, 20, 22, 60-62, 90-92, 95, 104, 116, 117.

${ }^{83}$ HR-DAZD-31-BZ, PP, b. 1, fasc. 4, fol. 14v, fasc. 8, fol. 27v, fasc. 17, fol. 38v.
} 
committed. ${ }^{84}$ According to the provisions of the Statute of Zadar, banishment was permanent for murder, theft and treason, and the perpetrators were not allowed to return to the city for the celebrations of St. Grisogonus (Krševan) as were other banished citizens. ${ }^{85}$ The son applies the same pattern of behaviour as the communal authority, which stems from the belief that in this way the curse for the blood spilled is lifted from the community and the individual.

Among the unusual contracts from the Perençanus's registry, one promissory note stands out. ${ }^{86}$ The reason for it was very unusual, and it was drawn up after the parties had made a dowry contract. The Zadar nobleman Damianus de Cipriano, on behalf of his goddaughter Fumia, the daughter of Iohannes of Rab, handed over a dowry of 200 livres of small dinars to her future husband Antonius of Venice, who is nunc habitator Iadre. ${ }^{87}$ Three days later, the future groom committed to the same nobleman that he would pay of 100 gold ducats of damages to Fumia if it was established that he had a living wife in Venice. ${ }^{88}$ That the charge of bigamy was serious, or rather that there was a possibility of deception before marriage, can be seen in the amount of the compensation as well as in the fact that another Venetian, also a habitator of Zadar, guaranteed for the possible payment. Clearly, the future groom had to commit to paying damages in the case of deception, encouraged by the eager godfather who had heard disturbing rumours that the groom might already be married.

Finally, the contract Carta iuramenti de vno matrimonio ${ }^{89}$ remains. From the narration of the contract, it follows that a dispute over the marriage between Stoia, the daughter of Stephanus, a habitator of Zadar and Perfçus, son of the late Vitus who lived in Crno. Namely, Stoia claimed she had married Perfçus by a marriage agreement in the present (per verba de presenti), ${ }^{90}$ which he firmly denied. Therefore, both parties made the decision to settle the dispute by having Perfçus swear before Georgius, the parish priest of St. Mary, that he had not married Stoia according to the law of the Roman Catholic Church. What really preceded this contract raises many open questions. ${ }^{91}$ Under the jurisdiction of which

${ }^{84}$ HR-DAZD-31-BZ, PP, b. 1, fasc. 13, fol. 22v. For the origin of banishment as a punishment see: Jaramaz-Reskušić, Kaznenopravni sustav u Šibeniku, 113-121.

${ }^{85} \mathrm{ZS}$, book V, chapter 36.

${ }^{86}$ For all that can be the subject of promissory notes see: "PDFA", 111-112

${ }^{87}$ HR-DAZD-31-BZ, PP, b. 3, fasc. 10, fol. 19v-20r.

${ }^{88}$ HR-DAZD-31-BZ, PP, b. 3, fasc. 10, fol. 20r.

${ }^{89}$ HR-DAZD-31-BZ, PP, b. 1, fasc. 5, fol. $2 \mathrm{v}$.

${ }^{90}$ For the marriage agreement per verba de presenti see: Janeković-Römer, Maruša, 136-141; Jutta Sperling, "Marriage at the Time of the Council of Trent (1560-70): Clandestine Marriages, Kinship Prohibitions, and Dowry Exchange in European Comparison", Journal of Early Modern History 8 (2004): 86, 88-90.

${ }^{91}$ For more on the matter of medieval marriage see: Janeković-Römer, Maruša, 121-160; Marija Mogorović Crljenko, Nepoznati svijet istarskih žena. Položaj i uloga žene u istarskim komunalnim društvima: primjer Novigrada u 15. i 16. stoljeću [The Unknown World of Istrian Women: Women's 
court was the dispute led? On the one hand, all marriage disputes fell under the jurisdiction of Church law and judiciary, while secular courts had jurisdiction over property issues related to dowries and inheritance, adultery, concubines and sexual offenses. ${ }^{92}$ On the other hand, canon law did not allow arbitration and outof-court settlements. ${ }^{93}$ Does the metacontext of that oath imply that the marriage was not in accordance with the Church's model, since only after the Council of Trent in 1563 was a church wedding with the presence of a priest required? ${ }^{94}$ Is there a clash between the concepts of church and secular models of marriage in this case, considering who witnessed the marriage (a clergyman or a layman) and considering the place where the marriage took place (sacral or secular space)? Did they marry through a mediator or was it a secret marriage? ${ }^{95}$ Why was the parish priest chosen to resolve this dispute? Does the choice of a clergyman imply that the Church had the authority to resolve disputes about the validity of marriage in view of the uncertainty as to how the marriage began? ${ }^{96}$ Namely, the most common lawsuits which were brought before ecclesiastical courts had to do with proving marital promises or agreements that usually took place in private, without witnesses, and the verdicts were mostly acquittals for the charged men. ${ }^{97} \mathrm{Be}$ that as it may, this contract is an example of a very unusual case, and the choice of the liberal parish priest to settle it is probably not accidental, for he was the uncle of the already mentioned Zadar nobleman Thadeus de Sgagno.

\section{The influence of spoken discourse in the selected papers}

The unusual details from the notarial records considered in this paper refer to people of various origins (Croatian, Dalmatian-Roman and Roman) who wo-

\footnotetext{
Position and Role in Istrian Commune Societies: Example of Novigrad in the 15th and 16th Century] (Zagreb: Srednja Europa, 2006), 39-76; Nikolić Jakus, Rođaci i bližnji, 52-60; Rudolf Weigand, Liebe und Ehe im Mittelalter (Goldbach: Keip Verlag, 1993); Georges Duby, Die Frau ohne Stimme. Liebe und Ehe im Mittelalter, aus dem Französischen von Gabriele Ricke, Ronald Voullié (Frankfurt am Main: Fischer Verlag, 1993), etc.

${ }_{92}$ Janeković-Römer, Maruša, 30

${ }^{93}$ Ibid. 72.

${ }^{94}$ For the decrees of the Council of Trent see: Janeković-Römer, Maruša, 132, 168, 173-176. For the difference between the church and the secular models of marriage see: Zrinka Nikolić, "Između vremenitih i vječnih dobara. Žene u dalmatinskim gradovima u ranom srednjem vijeku" [Between Earthly and Eternal Goods: Women in Dalmatian Cities in the Early Middle Ages], in: Žene u Hrvatskoj. Ženska $i$ kulturna povijest, ed. Andrea Feldman (Zagreb: Institut "Vlado Gotovac" Ženska infoteka, 2004), 43-44.

${ }^{95}$ For these kinds of marriages see: Janeković-Römer, Maruša, 139-140, 163-168.

${ }^{96}$ For the authority of secular and church courts see: Janeković-Römer, Rod i grad, 16-17; Popić, "Zadarske mirazne parnice iz druge polovice 14. stoljeća" [Dowry Litigations in Zadar in the Second Half of the Fourteenth Century], Zbornik Odsjeka povijesnih znanosti Zavoda za povijesne i društvene znanosti HAZU 30 (2012): 70. For the canon rules of married and family life and the differences between and the convergence of the secular and church conception of marriage see: Janeković-Römer, Rod i grad, 56-76.

${ }^{97}$ Janeković-Römer, Maruša, 161-163.
} 
uld come to Perençanus, a notary originally from Padua, so a question arises as to how much their speech affected the formulaic structure of these documents which were written in Latin.

The influence of speech, in which Roman, i.e. Italian, and Croatian prevail, on the discourse of official documents written in Latin is most evident at the lexical level in the form of various loanwords, i.e. Roman and Slavic words. In the analyzed writings, Roman words are more numerous.

Most of them refer to various occupations of people who appeared as contracting parties and witnesses (çapator, becarius, murarius, marangonus, chalefadus, marinarius, merçarius, draperius, laueçarius, capellarius) and their service (plaçarius) ${ }^{98}$ Most of these occupations are various crafts.

Then follow Roman words signifying various fabrics (fodra, grixus/grixius, stametum), items of clothing (capocium, mantellum, subtelarium), materials for clothing (coniglus), various objects (bursa, caldaria, cassella, feramentum, scarsela) and other individual words (çellus, gamba) ${ }^{99}$ All these Roman words which denote various fabrics and items of clothing as well as feramentum are essentially an integral part of service contracts and the written agreement that the contractors would not go to taverns on workdays, and are inserted into a formulaic promise of material and/or cash reward of an apprentice or worker (pacta/promissio within the formula res), as well as that of adhering to the agreement not to go to taverns on workdays. Caldaria and scarsela as Roman words that denote various objects are found in the name formula of two immigrants from the Apennine peninsula. The word caldaria in its synthetic form a caldariis ('from kettles') stands as the equivalent to the analytical form of the flexion of the noun calderarius in the name formula of the well-known Venturinus from Cesena. The second Roman word of scarsela in its synthetic form a scarselis ('from leather bags') can in part be considered a pejorative nickname in the sense of 'peddler', appearing in the name formula of the famous banker Peter from Florence. In a later period, this form was replaced by the analytical form of the word monetarius, which denotes the occupation of a 'banker'.

\footnotetext{
${ }^{98}$ HR-DAZD-31-BZ, PP, b. 1, fasc. 11, fol. 7v, 12v (çapator); HR-DAZD-31-BZ, PP, b. 1, fasc. 3, fol. 33v, fasc. 11, fol. 7r, fasc. 12, fol. 13 (becarius); HR-DAZD-31-BZ, PP, b. 1, fasc. 3, fol. 22v, fasc. 11, fol. $7 \mathrm{v}$ (murarius); HR-DAZD-31-BZ, PP, b. 1, fasc. 11, fol. 7v, 12v, b. II, fasc. 5, fol. 22r (marangonus); HRDAZD-31-BZ, PP, b. 2, fasc. 5, fol. 22r (chalefadus); HR-DAZD-31-BZ, PP, b. 1, fasc. 12, fol. 13r, b. 3, fasc. 10, fol. 20r, fasc. 12, fol. 2r, 2v, CD 16, dok. 132, 146 (marinarius); HR-DAZD-31-BZ, PP, b. 1, fasc. 13, fol. 23r, fasc. 14, fol. 16r, b. 3, fasc. 12, fol. 2r, 2v (merçarius); HR-DAZD-31-BZ, PP, b. 1, fasc. 3, fol. 22r, 22v, 33r, 33v (draperius); HR-DAZD-31-BZ, PP, b. 1, fasc. 1, fol. 8r (laueçarius); HR-DAZD-31-BZ, PP, b. 1, fasc. 5, fol. 2v (capellarius); HR-DAZD-31-BZ, PP, b. 1, fasc. 6, fol. 1r (plaçarius).

${ }^{99}$ HR-DAZD-31-BZ, PP, b. 1, fasc. 1, fol. 8r (fodra, stamentum, coniglus, çellus); HR-DAZD-31-BZ, PP, b. 1, fasc. 6, fol. 1r (grixus, capocium, mantellum, subtelarium, bursa, feramentum, gamba); HR-DAZD31-BZ, PP, b. 1, fasc. 10, fol. 33r (grixius left as a bequest); HR-DAZD-31-BZ, PP, b. 2, fasc. 1, fol. 30r (caldaria); HR-DAZD-31-BZ, PP, b. 1, fasc. 3, fol. 11r (cassella); HR-DAZD-31-BZ, PP, b. 1, fasc. 5, fol. $53 \mathrm{v}$ (scarsela).
} 
The remaining Roman words appear in a completely different context than the previous ones. Thus, bursa and gamba are at one point listed when a master promises to lend a gold florin out of his own pocket to treat his apprentice's leg; $c a-$ ssella is the subject of a receipt; and çellus is an abstract noun inserted in the usual adverbial phrase sponte, libere et ex certa scientia... set animo mero, puro, quieto et sincero et bono çellu se ex pacto insimul concorditer conuenerunt used to describe the verb convenire. In subsequent contracts, Perençanus omitted this noun from the aforementioned adverbial phrase.

In the selected records, only two Slavisms were found: banus as a mark of high office and poduorniça ('house plot'). The first word can usually be found in the datation formula. ${ }^{100}$ The second is in the will of Thadeus de Sgagno in a series of bequeathed legacies. Since the house plot which was bequeathed was located in the area of the villa Kamenjana, in the hinterland which was completely populated by Croats, it is not unusual for this Slavism to appear in a document written in Latin, with the testator mentioning it to the notary orally. The testator was obviously a descendant of a bilingual family judging by the name of one of his sisters, Dobriça.

Owing to the formulaic form of notary records, spoken discourse, at least in the case of Perençanus, did not affect the phonological, morphological and syntactic levels in terms of significant deviations from the usual changes in medieval Latin. ${ }^{101}$ The recorded influence of spoken language on the lexis also did not violate the diplomatic structure of the documents because individual Roman and Slavic words were used in the variable part of a formulaically set up part of documents designed for different variations within a particular type of notary document.

\section{Conclusion}

From the medieval notary records of the Zadar Commune, depending on the degree of their preservation, a lot of information is available which provides insight into the various aspects of the history of medieval Zadar (urban, legal, economic, social, etc.). These records were drawn up according to set forms compiled in notary handbooks which the notaries had become familiar with during their education in law at various universities, which made it easier for them to draw up certain types of contracts, files and other documents in Latin as the official language. It is precisely the way of compiling medieval notary records according to the set forms, as well as the content of legal business that was largely part of property law and law of obligations, that contributed to their uniformity. The records of Petrus called Perençanus, the notary from Zadar, in the second half of

\footnotetext{
${ }^{100}$ For Perençanus's notation of the datation formula see: Bartulović, "PDFA", 68.

${ }^{101}$ For the phonology and morphosyntax of medieval Latin see: Peter Stotz, Handbuch zur lateinischen Sprache des Mittelalters 1-5 (Zürich: Verlag C. H. Beck, 1996-2004).
} 
the fourteenth century are no different. His notary register contains a little short of 5000 contracts (unfortunately, most of them have not been completely preserved). In them, one can find only occasional details from personal lives of individuals in only 49 contracts whose content offers more that merely statistical value within the historical and economic context. Most of these details reveal aspects of everyday life in the medieval Zadar Commune in which legal regulations and the Christian worldview are intertwined, especially when it comes to the afterlife (the fear of eternal punishment, etc.). Such phenomena have been observed in the examples of contracts noting the following: admitting that an individual had acquired a house by fraud; various reasons that motivated the contractor to draw up the contract (the release of two serves after the end of their service, the release of responsibility for unintentionally causing a fire, the drawing up of a new instrument and the rejecting of one's father's possessions); the role of women in public life; agreeing to resolve disputes about whether or not marriage was concluded; the obligation to pay damages if it is established that the person is already married; wills related to illegitimate children. Other details (the buying two others serves, the mention of a possibility of mistaken identity, an agreement not to go to taverns on workdays, lodging of complaints, imprisonment) lack the colour of the Christian worldview. It can also be noted that most of the details are taken out of a wider context and thus they raise numerous questions to which it is impossible to provide answers, either because of the deficiency of other complementary sources or because the notary did not consider it necessary to give more in-depth explanations for their internal motivation.

Notary records are also important from the perspective of medieval Latin studies at the lexical, phonological, morphological and syntactic levels.

At the lexical level, Roman and Slavic words are the result of the influence of spoken language on the written discourse of the notary documents. Namely, when one considers the semantic fields (various occupations, types of cloth, objects) of Roman and Slavic words (regardless of their ratio), it is apparent that the words which entered the Latin corpus were those which reflected the sociolinguistic context of the commune that based its economic activity on trade and crafts (Roman words) and agriculture (Slavic words). These appeared mostly in the contrahentes and res formulae.

In the case of Perençanus, deviations from the norm at the phonological, morphological and syntactic levels as a result of the influence of spoken language have not been recorded, given the formulaic nature of the documents as well as the notary's education. Namely, the very few details which reflect everyday life vividly in no way undermine the formulaic nature of the contracts themselves. The reason for this should be sought in the fact that these details are most often an integral part of the formula causa, i.e. the part that gives the reason for the legal 
business: various reasons for donations, complaints, concluding agreements, rejecting one's father's possessions, issuing receipts, debentures or new contracts. A smaller number represents legal business incorporated in the contracts either in the formula res (buying of serves, an agreement not to go to taverns on workdays, obligation to pay damages if it is determined that the groom is already married, treatment of a leg (as pacta)), then in the conditional clause (returning of a legate if a problem with the person's identity arises) or finally in the subjects of legal business in capitulum legatorum of wills and codicils (illegitimate children).

The way in which this information is integrated into the notary records analyzed here suggests that Petrus Perençanus was not influenced by spoken discourse of his clients of various ethnic background (Croatian, Dalmatian-Roman and Roman) when he drew up his documents according to the set forms from notary handbooks he had learned during his studies to such an extent which would significantly alter the phonology and morphosyntax of his medieval Latin. However, changes at the lexical level are present and are the result of an invisible struggle in the sociolinguistic context between Latin as a language without native speakers and the vernaculars as living languages, Latin as a higher-level language and the vernaculars as lower-level languages, and Latin as the written medium and the vernaculars as oral media. 


\section{Archives}

Hrvatska - Državni arhiv u Zadru, Zadar - fond 31 - Bilježnici Zadra, Petrus Perençanus.

Hrvatska - Državni arhiv u Zadru, Zadar - fond 22 - Curia maior civilium

\section{Published Sources and Bibliography}

Bartulović, Anita. "Prilog životopisu zadarskoga bilježnika Petra Perencana (1365. - 1392.)”. Povijesni prilozi 50 (2016): 49-69.

Bartulović, Anita. "Paleografska, diplomatička i filološka analiza spisa zadarskog notara Petra Perencana (1361. - 1392.)”. Doktorska disertacija, Sveučilište u Zagrebu, 2014.

Benyovsky Latin, Irena. Srednjovjekovni Trogir: prostor i društvo. Zagreb: Hrvatski institut za povijest, 2009.

Benyovsky Latin, Irena; Begonja, Sandra. "Nekretnine u notarskim dokumentima 13. stoljeća: primjeri dalmatinskih gradova (Zadra, Šibenika, Trogira, Splita i Dubrovnika)”. Povijesni prilozi 51 (2016): 7-39.

Beuc, Ivan. "Statut zadarske komune iz 1305. godine”. Vjesnik Državnog arhiva u Rijeci II (1954).

Botica, Ivan. "Vlahi vlah - nekoć i danas". In: Jezik i identiteti, edited by Jagoda Granić, 61-69. Zagreb; Split: Hrvatsko društvo za primijenjenu lingvistiku, 2007.

Botica, Ivan. "Prilog istraživanju najstarijega spomena vlaškoga imena u hrvatskoj historiografiji”. Radovi 37 (2005): 35-46.

Budak, Neven. "Slavery in Late Medieval Dalmatia/Croatia: Labour, legal Status, integration”. Mélanges de l' école française de Rome. Moyen Âge 112 (2000): 745760.

Budak, Neven. "Pravni položaj serva i famula u komunalnim društvima na istočnom Jadranu”. Radovi Instituta za hrvatsku povijest 19 (1986): 51-68.

Budak, Neven. "Oslobađanje serva i ancilla i napuštanje upotrebe njihove radne snage na istočnom Jadranu”. Historijski zbornik 38 (1985): 115-130.

Budak, Neven. "Struktura i uloga obitelji serva i famula". Starohrvatska prosvjeta 14 (1984): 347-359.

Budak, Neven. "Trgovina radnom snagom na istočnom Jadranu - razvoj i značaj”. Historijski zbornik 37 (1984): 105-138.

Delić, Danko. "Proclamationes šibenskoga kneza Fantina de Cha de Pesaro (1441. - 1443.)”. Povijesni prilozi 35 (2008): 149-191.

Dokoza, Serđo. Zadarsko plemstvo, u tisku. 
Dokoza, Serđo. “Archivium comunis Jadre u XIV. stoljeću”. Radovi Zavoda povijesnih znanosti HAZU u Zadru 48 (2006): 215-230.

Duby, Georges. Die Frau ohne Stimme. Liebe und Ehe im Mittelalter. Aus dem Französischen von Gabriele Ricke, Ronald Voullié. Frankfurt am Main: Fischer Verlag, 1993.

Fabijanec, Sabine Florence. "Hygiene and commerce: the example of Dalmatian lazarettos from the fourteenth until the sixteenth century". Ekonomska i ekohistorija: časopis za gospodarsku povijest i povijest okoliša 4 (2008), no. 1: 115-133.

Fabijanec, Sabine Florence. "Društvena i kulturna uloga zadarskog trgovca u XIV. i XV. stoljeću". Zbornik Odsjeka povijesnih znanosti Zavoda za povijesne i društvene znanosti HAZU 22 (2004): 55-120.

Fabijanec, Sabine Florence. "Gospodarska djelatnost žena u dalmatinskom komunalnom području od XIV. do XVI. stoljeća”. In: Ženske skozi zgodovino. Zbornik referatov 32. zborovanja slovenskih zgodovinarjev, ed. Aleksander Žižek, 4964. Celje: Zveze zgodovnskih društev Slovenije, 2004.

Fabijanec, Sabine Florence. "Dva trgovačka inventara kao pokazatelji ekonomskog i kulturnog života u Zadru u XIV. stoljeću”. Povijesni prilozi 25 (2003): 93131

Fabijanec, Sabine Florence. "Pojava profesije mercator i podrijetlo trgovaca u Zadru u XIV. i početkom XV. stoljeća”. Zbornik Odsjeka povijesnih znanosti Zavoda za povijesne i društvene znanosti HAZU 19 (2001): 83-125.

Fabijanec, Sabine Florence. "Profesionalna djelatnost zadarskih trgovaca u XIV. i XV. stoljeću”. Zbornik Odsjeka povijesnih znanosti Zavoda za povijesne i društvene znanosti HAZU 17 (1999): 31-60.

Fossier, Robert. Das Leben im Mittelalter. Aus dem Französischen von Michael Bayer, Enrico Heinenmann und Reiner Pfleiderer. München; Zürich: Piper Verlag $\mathrm{GmbH}, 2008$.

Grbavac, Branka. "Notarijat na istočnojadranskoj obali od druge polovine 12. do kraja 14. stoljeća”. Doktorska disertacija, Sveučilište u Zagrebu, 2010.

Grbavac, Branka. "Zadarski notari u 13. i 14. stoljeću”. Magistarski rad, Sveučilište u Zagrebu, 2006.

Grbavac, Branka. "Svakodnevni život notara u jednoj kasnosrednjovjekovnoj dalmatinskoj komuni - primjer Zadra", Stara hrvatska svakodnevnica. In: Kolo. Časopis Matice hrvatske, edited by Vlado Bogišić, 161-177. Zagreb: Matica hrvatska, 2006.

Janeković-Römer, Zdenka. Maruša ili suđenje ljubavi. Bračno-ljubavna priča iz srednjovjekovnog Dubrovnika. Zagreb: Algoritam, 2007. 
Janeković-Römer, Zdenka. Okvir slobode. Dubrovačka vlastela između srednjovjekovlja i humanizma. Zagreb; Dubrovnik: Zavod za povijesne znanosti HAZU u Dubrovniku, 1999.

Janeković-Römer, Zdenka. "Na razmeđu ovog i onog svijeta. Prožimanje pojavnog i transcedentalnog u dubrovačkim oporukama kasnoga srednjeg vijeka". Otium 2 (1994), no. 3-4: 3-15.

Janeković-Römer, Zdenka. Rod i grad. Dubrovačka obitelj od XIII do XV stoljeća. Dubrovnik: Zavod za povijesne znanosti HAZU u Dubrovniku, 1994.

Jaramaz-Reskušić, Ivana. Kaznenopravni sustav u Šibeniku od 14. do 16. stoljeća. Šibenik: Gradska knjižnica "Juraj Šižgorić”, 1996.

Jelaska, Zdravka. “Trogirska srednjovjekovna obitelj”. Povijesni prilozi 18 (1999): 48-50.

Karbić, Marija. "Što znamo o nezakonitoj djeci u gradskim naseljima u međurječju Save i Drave tijekom srednjeg vijeka?”. Scrinia Slavonica 2 (2002): 168-177.

Klaić, Nada; Petricioli, Ivo. Prošlost Zadra II. Povijest Zadra u srednjem vijeku do 1409. Zadar: Filozofski fakultet, 1976.

Kolanović, Josip; Križman, Mate, eds. Zadarski statut: sa svim reformacijama odnosno novim uredbama donesenim do godine 1563. Zadar; Zagreb: Ogranak Matice hrvatske; Hrvatski državni arhiv, 1997.

Ladić, Zoran. Last Will: Passport to Heaven. Urban Last Wills from Late Medieval Dalmatia with special attention to the Legacies pro Remedio Animae and ad Pias Causas. Zagreb: Tiskara Zelina, 2012.

Ladić, Zoran. "O razlozima sastavljanja kasnosrednjovjekovnih dalmatinskih oporuka”. In: Raukarov Zbornik. Zbornik u čast Tomislava Raukara, edited by Neven Budak, 607-623. Zagreb: FF Press, 2005.

Le Goff, Jacques. Wucherzins und Höllenqualen. Ökonomie und Religion im Mittelalter. Aus dem Französischen von Matthias Rüb. Stuttgart: Klett-Cotta, 2008.

Le Goff, Jacques; Truong, Nicholas. Die Geschichte des Körpers im Mittelalter. Aus dem Französischen von Renate Warttmann. Stuttgart: Klett-Cotta, 2007.

Madunić, Domagoj. “Mjera grada. Zadarski popis stanovništva 1527. godine”. Povijesni prilozi 36 (2009): 23-63.

Malcolm, Noel. Povijest Bosne. Zagreb; Sarajevo: Erasmus Gilda, Novi Liber; Dani, 1995.

Margetić, Lujo. Hrvatsko srednjovjekovno pravo - obvezno pravo. Zagreb; Rijeka: HAZU; Pravni fakultet Sveučilišta u Rijeci, 1997.

Margetić, Lujo. Hrvatsko srednjovjekovno obiteljsko i nasljedno pravo. Zagreb: Narodne novine, 1996. 
Margetić, Lujo. Srednjovjekovno hrvatsko pravo - stvarna prava. Zagreb; Rijeka: Pravni fakultet Zagreb; Pravni fakultet u Rijeci, 1983.

McDougall, Sara. "Bigamy: A Male Crime in Medieval Europe?". Gender and History 22 (2010), no. 24: 30-46.

McKee, Sally. "Domestic Slavery in Renaissance Italy". Slavery and Abolition 29 (2008), no. 3: 305-326.

Mirdita, Zef. Vlasi u historiografiji. Zagreb: Hrvatski institut za povijest, 2004.

Mogorović Crljenko, Marija. Nepoznati svijet istarskih žena. Položaj i uloga žene u istarskim komunalnim društvima: primjer Novigrada u 15. i 16. stoljeću. Zagreb: Srednja Europa, 2006.

Mogorović Crljenko, Marija. "Žena u obitelji i društvu - prema odredbama Motovunskog statuta". Vjesnik Istarskog arhiva 8-10 (2003): 203-212.

Nikolić, Zrinka. "Između vremenitih i vječnih dobara. Žene u dalmatinskim gradovima u ranom srednjem vijeku”. In: Žene u Hrvatskoj. Ženska i kulturna povijest, edited by Andrea Feldman, 33-56. Zagreb: Institut "Vlado Gotovac" Ženska infoteka, 2004.

Nikolić Jakus, Zrinka. "Obitelj dalmatinskog plemstva od 12. do 14. stoljeća”. Acta Histriae 16 (2008), 1-2: 59-88.

Nikolić Jakus, Zrinka. Rođaci i bližnji. Dalmatinsko gradsko plemstvo u srednjem vijeku. Zagreb: Matica hrvatska, 2003.

Pezelj, Vilma; Štambuk Šunjić, Marija. "Pravni položaj žene prema lastovskom statutu iz 1310. godine". Zbornik radova Pravnog fakulteta u Splitu 50 (2013), no. 3: 525-539.

Pezelj, Vilma. "Neki elementi pravnog položaja žene u rapskom statutu iz 14. stoljeća”. Zbornik radova Pravnog fakulteta u Splitu 48 (2011), no. 1: 73-87.

Pezelj, Vilma. "Naznake pravnog položaja žene u srednjovjekovnom Zadru". Zbornik radova Pravnog fakulteta u Splitu 43 (2006), no. 3-4: 523-551.

Popić, Tomislav. Krojenje pravde. Zadarsko sudstvo u srednjem vijeku (1358. 1458.). Zagreb: Plejada, 2014.

Popić, Tomislav. "Zadarske mirazne parnice iz druge polovice 14. stoljeća”. Zbornik Odsjeka povijesnih znanosti Zavoda za povijesne i društvene znanosti HAZU 30 (2012): 57-85.

Radić, Željko. "Zatvor u srednjovjekovnom trogirskom pravu”. Hrvatski ljetopis za kazneno pravo i praksu 12 (2005), no. 1: 89-107.

Raukar, Tomislav. Studije o Dalmaciji u srednjem vijeku (odabrane studije). Split: Književni krug, 2007.

Raukar, Tomislav. Zadar u XV stoljeću. Ekonomski razvoj i društveni odnosi. Zagreb: Sveučilište, Centar za povijesne znanosti, Odjel za hrvatsku povijest, 1977. 
Ravančić, Gordan. "Prilog proučavanju Crne smrti u dalmatinskom gradu (1348. - 1353.) - raspon izvorne građe i stanje istraženosti na primjerima Dubrovnika, Splita i Zadra”. Povijesni prilozi 26 (2004): 7-18.

Ravančić, Gordan. "Historiografija o epidemiji Crne smrti”. Povijesni prilozi 33 (2007): 195-214.

Ravančić, Gordan. "Neka razmišljanja o prvome spomenu Vlaha". In: Poeta nascitur, historicus fit - ad honorem Zef Mirdita, ed. Albert Ramaj, 115-124. St. Gallen; Zagreb: Albanisches Institut; Hrvatski institut za povijest, 2013.

Ravančić, Gordan. Život u krčmama srednjovjekovnog Dubrovnika. Zagreb: Hrvatski institut za povijest; Dom i svijet, 2001.

Ravančić, Gordan. "Kvantifikacija svakodnevnice - primjer dubrovačkih krčmi”. Povijesni prilozi 39 (2010): 11-21.

Ravančić, Gordan. "Curia maior ciuilium - najstariji sačuvani registar građanskih parnica srednjovjekovnog Zadra (1351.-1353.)”. Radovi Zavoda povijesnih znanosti HAZU u Zadru 43 (2001): 85-160.

Smičiklas, Tadija et al., ed. Codex diplomaticus Regni Croatiae, Dalmatiae et Slavoniae 16. Zagreb: JAZU, 1976.

Sperling, Jutta. "Marriage at the Time of the Council of Trent (1560-70): Clandestine Marriages, Kinship Prohibitions, and Dowry Exchange in European Comparison", Journal of Early Modern History 8 (2004): 67-108.

Stipišić, Jakov. Inventar dobara Mihovila suknara pokojnog Petra iz godine 1385. Zadar: Stalna izložba crkvene umjetnosti u Zadru, 2000.

Stotz, Peter. Handbuch zur lateinischen Sprache des Mittelalters 1-5. Zürich: Verlag C. H. Beck, 1996-2004.

Šanjek, Franjo, ed. Fenomen "krstjani" u srednjovjekovnoj Bosni i Humu. Zbornik radova. Sarajevo; Zagreb: Institut za istoriju; Hrvatski institut za povijest, 2005.

Šanjek, Franjo. Bosansko-humski krstjani i katarsko-dualistički pokret u srednjem vijeku. Zagreb: Kršćanska sadašnjost, 1975.

Šišić, Ferdo. Vojvoda Hrvoje Vukčić Hrvatinić i njegovo doba (1350. - 1416.). Samobor; Zagreb: A. G. Matoš; Naklad Hrvoje, 2004. (pretisak izdanja iz 1902.).

Šupuk, Ante. "Šibenski Liber baptizatorum (1581 - 1590), njegova antroponimna građa i osobitosti te antroponimije". Radovi 7 (1975): 81-186.

Weigand, Rudolf. Liebe und Ehe im Mittelalter. Goldbach: Keip Verlag, 1993.

Witte, John, Jr. "Why Two in One Flesh? The Western Case for Monogamy over Polygamy”. Emory Law Journal 64 (2015): 1677-1746. 


\section{Anita Bartulović}

\section{Neuobičajeni detalji iz svakodnevnoga života iz bilježničkoga registra zadarskoga bilježnika Petra zvanoga Perencan (1365. - 1392.)}

\section{Sažetak}

Kao obrazac za sastavljanje srednjovjekovnih bilježničkih spisa pisanih na latinskome jeziku u upotrebi su bili različiti priručnici. Tako su se bilježnici zadarske komune druge polovice 14. stoljeća, a među njima i Petar zvan Perencan iz Padove (1365. - 1392.), koristili priručnikom bolonjskoga profesora Rolandina Pasagerijeva Summa artis notariae koji je sastavljen sredinom 13. stoljeća. S obzirom na formulaično oblikovanje tih spisa kao i činjenice da sadržaj pravnih poslova pripada većinom sferi stvarnoga i obveznoga prava, među tisućama sačuvanih dokumenata iz četiriju busta Perencanova bilježničkoga registra može se izdvojiti tek četrdesetak njih koji donose neke neuobičajene i živopisne detalje iz osobnoga života pripadnika zadarske komune različite etničke pripadnosti i društvenih slojeva.

Analizom civilizacijskoga konteksta izdvojenih detalja utvrđeno je da oni ne narušavaju formulaičnost iskaza jer imaju svoje utvrđeno mjesto u diplomatičkoj strukturi dokumenata. Detalji koji se odnose na više-manje uobičajene pojavnosti ili stavove kao i na društveno neprihvatljive oblike ponašanja u svakodnevnici srednjovjekovlja najčešće su integralni dio različitih vrsta ugovora i dokumenata u pojedinim formulama. Tako se $\mathrm{u}$ formuli causa spominju: požar, epidemija kuge, javno mnijenje o ženi u javnome životu, različiti izrazi emocionalnosti, kazne zatvorom, ubojstvo, mogućnost bigamije. U formuli res nalazi se: oslobađanje od odgovornosti za nehotično počinjeni požar kao i obveze vraćanja legata ako se utvrdi zamjena identiteta, kupovina serva, ugovorno utvrđen dogovor da se ne zalazi u krčme radnim danom, potvrda o primitku škrinje u vlasništvu zasužnjenih osoba, različiti prigovori, ugovaranje službe za nezakonito dijete, sporazum o razrješenju spornoga braka. U nešto manjoj mjeri unutar formule res kao pacta/promissio nalaze se dogovor o liječenju noge i obećanje o oslobođenju serva; a u capitulum legatorum nezakonita djeca ili u contrahentes oporučni izvršitelji nezakonite djece.

Analiza jezičnoga konteksta bilježničkih spisa iz kojih su izdvojeni neuobičajeni detalji pokazuje da govorni diskurs stranaka (dalmato-romanski, hrvatski, romanski) nema odraza na fonološkoj, morfološkoj i sintaktičkoj razini pismenoga diskursa (latinski), ali ima na leksičkoj razini. Na leksičkoj razini zabilježeni romanizmi i u manjoj mjeri slavizmi također ne narušavaju formulaičnu strukturu tih dokumenata te su najčešće integralni dio formula contrahentes (oznake zanimanja u denominaciji stranaka) i res (tkanine, odjevni

\footnotetext{
"Anita Bartulović, Odjel za klasičnu filologiju, Sveučilište u Zadru, Obala kralja Petra Krešimira IV. br. 2, 23000 Zadar, Hrvatska, E-mail adresa: abartulo@unizd.hr
} 
i ostali predmeti kao pacta/promissio). Najveća zastupljenost posuđenica u navedenim formulama na slikovit način odražava sraz vernakularnih jezika kao jezika izvornih govornika čiji je leksik našao mjesto upravo u promjenjivome dijelu formulaičnoga obrasca bilježničkih dokumenata pisanih na službenome latinskom kao jeziku bez izvornih govornika.

Ključne riječi: srednji vijek, Zadar, bilježnički spisi, Petar Perencan, srednjovjekovni latinski jezik, pisani diskurs, govorni diskurs 